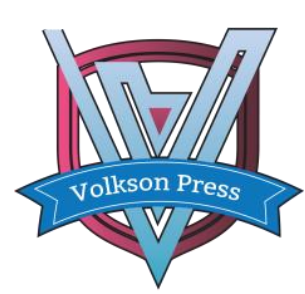

Contents List available at VOLKSON PRESS

Economics \& Management Innovations(EMI)

DOI : http://doi.org/10.26480/icemi.01.2017.196.197

\title{
A time series analysis on the relationship between Gross fixed capital, Labor force and Economic growth in China
}

Pu Ruihui ${ }^{1, *}$, Guo Jing ${ }^{2}$

${ }^{1}$ Dhurakij Pundit University, Thailand

${ }^{2}$ Dhurakij Pundit University, Thailand

ruihui.pu@dpu.ac.th

This is an open access article distributed under the Creative Commons Attribution License, which permits unrestricted use, distribution, and reproduction in any medium, provided the original work is properly cited.

\section{ARTICLE DETAILS}

\section{Article History:}

Received 02 october 2017 Accepted 06 october 2017 Available online 11 october 2017

\section{Keywords:}

Economic Growth, Gross fixed capital, Gross Domestic Product, Labor force, ADF unit-root test, Economic policies, causality, time series data...

\section{ABSTRACT}

from year 2000 to 2015, China's GDP growth rate has rapidly increased and specifically it has reached the level at $11.4 \%$. This paper is to test the relationship between gross fixed capital (constant: USD), labor force and economic growth and the potential economic policies will be suggested in corresponding to the results. The method of data analysis will be using the ADF unit-root test and finally the Granger causality test will be applied to test the correlation both in long term and short term. Causality is examined between gross fixed capital, labor force and gross domestic product. Therefore, the results reveal that there has long-run causality deriving from labor force or gross fixed capital to economic growth. In the short-run, there is no causality between labor force and economic growth.

\section{Introduction}

Various factors which affect the economic growth in the process of promoting the economic growth played the role and status of will be constantly changing in China. This chapter mainly analyzes the quantity of labor force, gross fixed capital effect on China's recent economic growth, with emphasis on the in the current stage of economic development to promote the growth of China's economy. However, Gross fixed capital formation is a macroeconomic concept applies in official national accounts such as the United Nations System of National Accounts (UNSNA), National Income and Product Accounts (NIPA) and the European System of Accounts (ESA). Statistically it measures the value of acquisitions of new or existing fixed assets by the business sector, governments and "pure" households (excluding their unincorporated enterprises) less disposals of fixed assets. In China, the long-term implementation of the investment to support growth, with the accelerating process of urbanization in China, China's economic growth mode to rely on investment and on natural resources development and utilization to further accelerate the accumulation of capital. At the same time, along with the urbanization process in China opened the investment demand is strong, the real estate market also played a strong supporting role. These factors comprehensive investment pulling China's economic growth provides a good condition. In addition, Capital and labor forces are the primary factors of economic growth for China. From the classical growth theory to the new growth theory, the contribution of capital and labor has been made attention to. Hence, I utilize the labor force and gross fixed capital to measure the output (economic growth). Labor force is likewise the principal factor in economic growth. Economic growth is not only subject to the attention of governments and residents. But also an important aspect of the study of monetary theory. However, China still faces the problem of insufficient capital input and invest particularly in education and some technology experiments. Therefore, this paper is to study on the relationship between gross fixed capital in constant, Labor force and economic growth (GDP) and the result shows that labor and capital are positively affecting the economic growth in China based on economic theory. As a result of China's implementation of the mandatory family planning policy. It can be predicted that in 2017 the number of employment in our country will be further reduced, and the number of retirees will be further increased. At present, China's rural labor shortage has begun to show. Moreover, the labor force and capital are the main factors to devote to economic growth based on Keynes's macroeconomic model. In this paper, I would like to discuss how does labor and gross fixed capital effects on economic growth in China by utilizing the ADF model to examine the related relationship and check the relationship for both the short-run and long-run relationship.

\section{RELATED LITERATURE}

Gregory C. Chow (1993) indicates in the article that China's economic reform toward a market-oriented economy began in 1978 and has been regarded as essentially productive. The average rate of growth of GDP in the decades of reforming was about 9.6 percent annually according to official statistically. The results show that capital in China includes the folk tradition of hard work and entrepreneurship, and the high regard for education.'s: Capital is sufficient for profitable growth, then growth can take place under different forms of government. Dick Lo(2002) mentions that in the "Chinese Economy growth and labor employment" indicated that they says that the China-specific development that, in the first half of the reform era, industrialization mainly took the form of widening rather than deepening - industrial growth and overall economic growth were in a large measured propelled by the massive transfer of labor force from agriculture to industry. However, labor compensation expansion and capital-deepening growth. Gregory C Chow (2004) mentions in Capital formation and economic growth in China that the explanation of technological progress without which any theory on the growth of western economies is deficient. with capital formation playing an important role as the Chinese economic planners and Solow's theory intended. David Dorn(2013) says that rising imports cause higher unemployment, lower labor force participation, and reduced wages in local labor markets that house import-competing manufacturing industries. of our main specification, import competition explains one-quarter of contemporaneous aggregate decline in U.S. manufacturing employment. Transfer benefits payments for unemployment, disability, retirement, and healthcare also rise sharply in more trade-exposed labor markets. Xinjiang Zhao(2008), mentions that Holz (2006) explores this issue in detail about labor force and adjusts the labor data before 1990, so that the labor data is consistent before and after 1990. To conclude,without improvement of labor quality and accumulation of capital, China's economic growth rate would be lower. There are numerous channels through which capital 
contributes to economic growth. One is as an input like physical capital since more capital inputs increase output. In this sense, it is effectively a quantitative increment of labor. New growth theory indicates that the accumulation of capital can incline the production of new ideas and innovation so that technology levels will improve, and increase productivity. Under this view, capital is more than an input, and it should be thought an additional input enhancing. The more capital is accumulated, the more the chance of technology improvement and innovation, the higher the productivity of production, and more output results from the same inputs.

\section{THEORETICAL FRAMEWORK}

The Granger causality test will be adopted for this study which is a statistical hypothesis test for determining whether one time series is useful in forecasting another future value of a time series (Granger, C. W. J. 1969). Granger causality test helps to explore the short and long-run dynamic relationships among the grossed fixed capital, labor force, economic growth. The estimated long-run causal relationship among variables is based on the error correction model (ECM). The error correction term is required in testing Granger causality as follows by Granger et al (2000);

$$
\begin{aligned}
& \Delta \mathrm{y}_{\mathrm{t}}=\alpha_{0}+\gamma_{1}\left(y_{t-1}-\emptyset x_{t-1}\right)+\sum_{i=1}^{k} \alpha_{1 i} \Delta y_{t-1}+\sum_{i=1}^{k} \alpha_{2 i} \Delta x_{t-1}+ \\
& \varepsilon_{1 t} \\
& \Delta \mathrm{y}_{\mathrm{t}}=\beta_{0}+\gamma_{2}\left(y_{t-1}-\emptyset x_{t-1}\right)+\sum_{i=1}^{k} \beta_{1 i} \Delta y_{t-1}+\sum_{i=1}^{k} \beta_{2 i} \Delta x_{t-1}+\varepsilon_{2 t}
\end{aligned}
$$

Where $\gamma_{1}$ and $\gamma_{2}$ represent the speed of adjustment, and the $\left(y_{t-1}-\right.$ $\left.\emptyset x_{t-1}\right)$ represents the error correction term. The null hypothesis for equation is that $H_{0}: \alpha_{21}=\alpha_{22} \ldots=\alpha_{2 i}$ and $\gamma_{1}=0$ in case of rejecting the null hypothesis, this means that $x_{t}$ does Granger cause $y_{t}$. The null hypothesis for equation is that $H_{0}: \beta_{21}=\beta_{22} \ldots \beta_{2 i}=0$ and $\gamma_{2}=0$ in case of rejecting the null hypothesis, this means that $y_{t}$ does Granger cause $x_{t}$.

\section{METHODOLOGY AND DATA}

Testing for stationary of the variables used in the study using Augmented Dickey-Fuller (ADF) unit root test. In this stage, there are three variations of ADF test designed to take account of the constant term and the trend.

$$
\begin{aligned}
& \Delta Z_{t}=\gamma Z_{t-1}+\sum_{i=1}^{p-1} c_{i} \Delta Z_{t-1}+\varepsilon_{t} \\
& \Delta Z_{t}=\beta_{0}+\gamma Z_{t-1}+\sum_{i=1}^{p-1} c_{i} \Delta Z_{t-1}+\varepsilon_{t} \\
& \Delta Z_{t}=\beta_{0}+\beta_{1} t+\gamma Z_{t-1}+\sum_{i=1}^{p-1} c_{i} \Delta Z_{t-1}+\varepsilon_{t}
\end{aligned}
$$

$Z_{t}$ and $Z_{t-1}$ represent each variables at time $\mathrm{t}$ and time $\mathrm{t}-1 . \gamma, \beta_{0}$, and $\beta_{1}$ are constants. $\mathrm{T}$ is time trend. $\varepsilon_{t}$ are error series.The hypothesis of unit root test is as followed;

$$
\begin{aligned}
& H_{0}: \gamma=0 \text { (Series } Z_{t} \text { is nonstationary) } \\
& H_{1}: \gamma<0 \text { (Series } Z_{t} \text { is stationary) }
\end{aligned}
$$

To decide whether the series are stationary or not, the ADF test statistic is compared with the p-value.We formulate a function as follows:

$\operatorname{LnGDP}=\boldsymbol{\beta}_{1}+\boldsymbol{\beta}_{2} \operatorname{Ln} \boldsymbol{L}+\boldsymbol{\beta}_{3} \operatorname{Ln} K+\boldsymbol{\mu}$ Whereby, SLPP:LogGDP is the log of Gross domestic product (Current:USD) devotes to the economic growth of China.septogL is the log of Labor Forces Gross fixed capital (constant:USD).

\section{EMPIRICAL RESULTS}

The results for this test indicated that all the variables are non-stationary at level (p-values are more than $10 \%$ level of significance) and stationary at first difference ( $p$-values are less than $50 \%$ level of significance). As we tested shows that GDP, Capital and Labor force are non-stationary in lever $\mathrm{I}(0)$. But stationary in the first difference level I(1), the result for all variable indicates that they are significant at $5 \%$ significant level except Labor on intercept and trend are significant at 5\% significant level, which means that all variable are stationary. First, find the min value of LAG SELECTION $=2$ under AIC( Akaike Information Criterion). there are At least two long run relationships or co-integration variables and represents the Johansen trace statistics and maximal Eigenvalue test for cointegration based on a VAR using the optimal lag length of 2 . The result shows there is at least 2 cointegrating vector at the $5 \%$ significance level. Moreover, the table also shows that by using trace test, there are two co-integrating equation have found at $5 \%$ significant level. Co-integration shows that there has long-run relationship exists between capital, labor force and economic growth in China. Since the p-value of Log(Capital) and Log(Labor) are both less than significant level at 0.05 , means that the past value of the Capital and Labor force is effecting the China's economic growth and it can be used to predict in the long-run relationship. It also shows that there have long-run granger causality from labor or capital to gross domestic product although there has a positively long-run effect of GDP to both labor and capital. Therefore, it reveal that the theory that when the economy is growing, it influences the expansion of capital and labor, and when the gross fixed capital and labor force increase, the output can be positively increased. Test results for short-run causality is that at $5 \%$ significance level. First, in the short-run for the gross fixed capital does cause changes in GDP. Second, GDP does not Granger cause labor force as well. Third, in the short-run change in labor force does not cause changes in long-term gross fixed capital. However, we can conclude that the change in long-term gross fixed capital does Granger cause economic growth with $5 \%$ significance level and the past change in gross fixed capital also have impact on labor force.

\section{CONCLUSION AND POLICY IMPLICATION}

This paper analyze the relationship between gross fixed capital, total labor force and economic growth in China by using the ADF model in cointegration. Through the empirical analysis, In the first part of the result shows that there is long-run relationship between the gross fixed capital, total labor force, and economic growth at 0.01 significance level which a one percent change. There has a co-integrating equation exists, thus implying the long-term relationships between economic growth, gross fixed capital and total labor force and the results of the VECM test that there has a both long-term relationship and short-term relationship. The results of the Granger causality model show that in China, gross fixed capital influence on economic growth. Increase investment in human resources, labor productivity can be improved, especially increase the training of migrant workers should be as the important contents of the workers of the future training and the large number of migrant workers, improve the overall quality of migrant workers will be significance to the development of economic growth.spepiplicy recommendations for maintaining a prosperous chinese economic growth, healthy and stable labor market is extremely important for China's future and reform. Labor market can to promote the adjustment of economic structure, smooth realization of transformation and upgrading and help to create wealth spillovers, start private investment, stimulate consumption, contribute to successfully resolve the local debt crisis, the stability of the local economic development, conducive to the real estate to inventory and clearing the debt, the debt to resolve provide space and platform, assist in repair of the national balance sheet, to enhance national competitiveness, contribute to the smooth realization of the "road in the vicinity of the national strategy, help the Chinese high-end equipment and manufacturing going out.

\section{References:}

[1] Chow, Gregory C., 1985, The Chinese Economy. New York: Harper and Row. Chow, Gregory C., 1986, Chinese statistics. The American Statistician 40, 191-196.

[2] Chow, Gregory C., 1993, Capital formation and economic growth in China. Quarterly Journal of Economics 108, 809-842.

[3] Dic LO School of Oriental and African Studies, University of London, UK; and School of Economics, Renmin University of China, China

[4] David H. Autor, David Dorn, and Gordon H. Hanson*The China Syndrome: Local Labor Market Effects of Import Competition in the United States

[5] Xiliang Zhao Working Paper 16592 NATIONAL BUREAU OF ECONOMIC RESEARCH

[6] David H., and Daron Acemoglu. 2011. "Skills, Tasks and Technologies: Implications for Employment and Earnings." In Handbook of Labor Economics, Vol. 4B, edited by Orley Ashenfelter and David Card, 10431171.

[7] Dorn, David. 2009. "Essays on Inequality, Spatial Interaction, and the Demand for Skills." Dissertation, University of St. Gallen no. 3613 